DOI 10.14746/ssp.2018.3.5

Grażyna PIECHOTA

Andrzej Frycz Modrzewski Kraków University

Robert RAJCZYK

University of Silesia in Katowice

\title{
Institutionalization of Ukraine's information policy as a function of strategic communication
}

\begin{abstract}
The paper presents the contemporary information policy implemented by the Ukrainian government. The survey answers the question about the new role of information policy in the state authorities' activities. The research focuses on the executive branch of power, due to its impact on the internal and external image of Ukraine. The analysis was conducted at the strategic, institutional and operational levels, and concerned the content of messages.
\end{abstract}

Key words: information policy, UATV, Revolution of Dignity, Ministry of Information Policy, Ukraine

\section{Introduction}

The 'Revolution of Dignity' which took place in Independence Square in Kiev from November 2013 to February 2014 significantly influenced the perception of Ukraine in the international arena. The organizers of the protests in Kiev won fame and the acclaim of the international community for effective communication mainly through social and content media. On the one hand, the choice of communication channels stemmed from the specific nature of the Ukrainian media market, and on the other hand it was mainly determined by the technical reach of the new media. The leaders of the protests and their organizers communicated with the recipients in a deliberate and coordinated way. Roscigno and Danaher emphasize the importance of content disseminated on networks during protests (Roscigno, Danaher, 2001). Activists (protest leaders) want to influence public opinion, so they engage users in creating news in such a way that the stories told reach the hearts of the interested people (Juris, 2005; Mutz, Young, 2011; Seib, 2012, p. 145; Turcotte, York, Irving, 
Scholl, Pingree, 2015). The communication from participants of events in Independence Square was organic in its nature (Piechota, Rajczyk, 2015; Hubenko, Wall, 2018). Limitations in using traditional media, especially television, playing an important role in building the Ukrainian information space, resulted mainly from the ownership structure of the TV broadcasters. State TV channels were subordinated to the government, as were those owned by the Ukrainian oligarchs supporting it. As Gemma Edwards remarks, new media influence the process of mobilization of individuals who use their smartphones to publish films on content websites and to comment on events in social media, contributing to the development of independent media (Edwards, 2014, p. 63). The use of Internet channels in mass communication during the protests was important. Castells emphasizes the growing role of network communication during protests, pointing to its existence outside of state control, in real time, in a way increasing interactivity and personalization of the message (Castells, 2006, p. 211; Gil de Zuniga, Puig-i-Abril, Rojas, 2009; Castells, 2013, pp. 212-219; Weeks, Holbert, 2013). The Internet during protests was a communication platform ensuring a technical reach comparable only with global TV information channels. They used and duplicated content published in social media, both by the main leaders of the Revolution of Dignity and other participants of the events in Kiev. Using content media, the global media created their own content, publishing highly credible messages. The lack of a political manager of messages, and also using modern forms of journalism that are attractive for the viewer, such as live video reports, ensured a significant social reach for two Internet TV channels: hromadske.tv and espresso.tv. (Rajczyk, 2016, pp. 109-110.) The social reach built as a result of live reporting of the events on Maidan square enabled the channel hromadske.tv to become one of the terrestrial TV operators after the events at the Euromaidan. In the Ukrainian situation of digital exclusion, this also entails the commercial success of the enterprise.

Communication during the events on Kiev's Maidan served an informative function, and the function of aggregating social capital. It was used both to gain political and material support for the protesters. Both functions were characterized by coherence of message and unity of objectives. As Reznik (2016) claims, this was shown in a consistent, pro-European narration based on the criticism of the refusal by President Viktor Yanukovych to sign the association agreement between Ukraine and the European Union, and then consistent, anti-system rhetoric stemming 
from the message, emphasizing anti-corruption issues and the necessity of systemic changes. ${ }^{1}$

The change in the Ukrainian government brought about a change of both the methods and objectives of the government's information policy. In the first phase, that ended on May 25, 2014 with the snap presidential elections, the information policy should be treated as a tool enabling the consolidation of external and internal political support for the temporary state authorities. However, a turning point in these communication activities was the annexation of Crimea by the Russian Federation and the commencement of the counter-terrorism operations in Luhansk and Donetsk oblasts, connected with the proclamation of the Luhansk and Donetsk People's Republics. The conflict of information around the annexation of Crimea in all its stages (occupation of the peninsula by the so-called 'little green men,' the 'independence' referendum and incorporation to the Russian Federation) has demonstrated the information supremacy of the Russian side. Public support for the annexation of Crimea both in the peninsula itself and in Russia resulted mostly from the systemic character of Russian propagandist influence and propaganda intoxication of the ethnic Russians dominating in the social structure of Crimea.

This systemic nature of propagandist influence encompasses all spheres of social life, its principles are complementary to each other and correlated with the system of traditional cultural values. It uses elements of social engineering, e.g. in the form of universal propagandist clichés - mainly the ethos of fighting fascism and victory in World War II. The condition necessary for propaganda intoxication to be effective is also its coherence with the values held by the recipient and their view of the world, shaped as a result of propagandist influence. Economic and ethnic factors also become important in such a case. The strong national identification of a significant part of Crimean residents, combined with the national lability of the inhabitants of the eastern oblasts of Ukraine, influenced the effectiveness of the political and communicative influence of the Russian side. ${ }^{2}$ However, it should be emphasized that Ukrainian activities in the

${ }^{1}$ Examples of anti-corruption issues include: the presentation of members of the government formed by Arseniy Yatsenyuk to protesters in Maidan or creating a special anti-corruption office headed by one of the leaders of protests in Independence Square.

${ }^{2}$ For more on this issue see: Regarding The Information - Psychological Component of Aggression of The Russian Federation Against Ukraine, http://en.niss.gov.ua/ public/File/englishpublic/Russia_aggression.pdf, Nov. 13, 2017. 
information war over Donbas against Russia have changed significantly since the unilateral declaration of the self-proclaimed Donetsk People's Republic, mainly in the strategic and institutional aspect, but also on the operational level, being included in the issues of information security.

\section{Research methodology}

The study was carried out on the basis of a quantitative analysis of the content of strategic documents, legislation and gazettes issued by government bodies with a particular focus on the Ministry of Information Policy of Ukraine. The analysis encompassed documents issued from January 14, 2015, when under the resolution of the Cabinet of Ministers of Ukraine the Ministry of Information Policy was created. The assessment of the effectiveness of Ukrainian information policy is based mainly on the correlation between strategic objectives and their implementation in communication practice. Such an analysis takes into consideration the strategic, institutional and operational aspects. To this end, a main research hypothesis was adopted which assumes that Ukraine's information policy is a function of information security, and the specific hypothesis emphasizing the secondary role of information policy compared with the strategic communication of the state. The following research questions were used for problem analysis: (1) what factors determine Ukrainian information policy? and (2) how is Ukrainian information policy connected with the strategic communications of the Ukrainian state?

The two-year research perspective is not wide, but it does allow us to formulate conclusions and make a possible evaluation. The choice of the period for the purposes of the analysis was dictated by the institutionalization of information policy and reorientation of strategic communications of the Ukrainian state caused by the geopolitical changes which are an effect of the Revolution of Dignity and new phenomena triggered by it in the communication sphere. In the strict sense, this mainly concerns the impact of the ideological and narrative propagandist media, while in the broad sense it is about the information security of the state (Rajczyk, 2016, p. 75). In the research process, the number of users of content published on selected information channels in social and content media was also counted. This made it possible to reveal the structural effectiveness of the information policy carried out in its utilitarian context. 
The analysis of research problems should be preceded by a review of definitions. The topic of this article requires the precise definition of the notion of information policy. According to Renata Maćkowska, information policy is "undertaking information activities" (Maćkowska, 2010, p. 141). However, considering the specific character of the research issues tackled in this article, the wider context of information influence should be indicated. In the narrow sense, information policy as described above is the topic of analysis here. From a broader perspective, though, the whole process of public communication should also be taken into consideration. According to Bogusława Dobek-Ostrowska, such communication is a process formally occurring "in a certain communication (information) space aimed at providing and exchanging information for public use and maintaining social relations by the public institutions responsible for this process" (Dobek-Ostrowska, 2006, p. 122).

The specific nature of the information policy carried out by Ukrainian state authorities encourages presenting it in the context of strategic communication, which is defined as "concentrated processes and efforts undertaken in order to understand and engage key audiences (recipients) to create, enhance or preserve conditions favorable for promoting national interests and objectives by using coordinated information, topics, plans, programs and activities synchronized with undertakings carried out by other elements of state authorities" (Kacała, Lipińska, 2017, p. 25) The US State Department includes the following issues in strategic communication: information operations, public diplomacy, international radio and TV broadcasting as well as public affairs - information and press activities (Kacała, Lipińska, 2017, p. 26).

The above typology has been applied for the purposes of this article, but with the exclusion of public diplomacy. This exclusion is due to the approach to the subject made on the basis of the definition proposed by Beata Ociepka, defining this type of diplomacy as "a bilateral, dialogic form of political international communication, targeted at the public abroad, implemented thanks to mass media and through direct channels. Its aim is to shape or enhance a positive image of a country and society abroad, shaping positive attitudes towards the sender" (Ociepka, 2008, p. 12). However, Ociepka emphasizes that public diplomacy is "one of the most effective instruments of international positioning of the state by using its soft resources. It is thus an instrument consciously applied by states in order to make their soft power resources recognized (the internal dimension of public diplomacy) and then used in foreign policy" (Ociepka, 2013, p. 70). 
According to this definition, public diplomacy is an instrument for implementing the foreign policy of a state, and by using so-called soft power it serves the purpose of shaping the external image of a country. The creator of the soft power concept - J. S. Nye (2007), states that for a given country the most important thing is the "policy of attracting others." This is achieved not only through offering a good product but also through promotional campaigns. This concerns, among other things, cultural diplomacy. Public diplomacy should thus be clearly differentiated from information policy, despite the fact that, undoubtedly, in a wider sense, these are also communication activities, clearly persuasive in their nature. The role of the media in creating the image of a country leads to a situation where media organizations are treated as symbolic elites that are needed to participate in the transmission of the image (Eisenstadt, Giesen, 1995). They not only make the selection of the image, but first of all communicate it to groups of recipients. ${ }^{3}$ According to Krzyżanowski (2008), they also hold temporary power over the discourse that is taking place.

To sum up the outline of definition issues, it is worth pointing out that the subject of this analysis is the different dimensions of information policy understood in its narrow sense as information activities, including information operations, international TV and radio broadcasting as well as information and press activities.

An original concept including information policy in strategic communication is proposed by the Information Security Doctrine of Ukraine - a document defining the national interests, directions and priorities of the state in the communication sphere, and its threats. It also treats the said information policy as part of the strategic communication of the Ukrainian state, which is defined as the coordinated application of communication potential to promote state interests. ${ }^{4}$

It is also worth focusing attention on the notion of information security. This term does not have an unambiguous definition. In the litera-

${ }^{3}$ A. Buhmann and D. Ingenhoff $(2015$, p. 102) present a similar opinion: "Research shows that the image of a country, as the cognitive representation that a person holds about a given country has a wide range of effects: country images critically influence foreign direct investment, the prosperity of national tourist industries, the attractiveness of domestic labor markets and educational systems as well as the stability of international relations and the degree of a country's political influence in the international system."

${ }^{4}$ Cf.: Ukaz Prezydenta Ukrayiny vid 25 lyutoho 2017 roku No. 47/2017 Pro Doktrynu informatsiynoyi bezpeky Ukrayiny, http://www.president.gov.ua/documents/472017-21374, Nov. 6, 2017. 
ture on the subject, we can find approaches to information security as "an element of an IT system synonymous to computer, telecommunication and network security" (Więcaszek-Kuczyńska, 2014, p. 212). Lidia Więcaszek-Kuczyńska is quoting a definition by Eugeniusz Nowak and Maciej Nowak, which is important from the point of view of the subject matter of this article approaching information security as "the state of external and internal conditions allowing a country to freely develop its information society." Due to the topic of this article, information security will be interpreted according to Eugeniusz Nowak and Maciej Nowak's definition (Więcaszek-Kuczyńska, 2014, p. 213).

\section{Strategic dimension of information policy}

Information security as a separate category appears first of all in the Ukrainian Constitution, listed alongside the protection of sovereignty and territorial integrity. ${ }^{5}$ Article 17 of Ukrainian fundamental law points to the necessity of ensuring information security as one of the most important functions of the state, alongside economic security, protection of sovereignty and territorial integrity. However, it should be emphasized that in the quoted article the Ukrainian Constitution gives responsibility for security issues to the Armed Forces and government bodies safeguarding the state.

Undoubtedly, even the preparation of the Information Security Doctrine of Ukraine is an implementation of the constitutional guarantees stemming from Article 17. In the narrow aspect, this doctrine is an answer to the Russian incursion into Ukrainian information space, since the aim of the document is the formulation of the principles of implementation of state information policy, which first of all is to counteract the destructive information influence of the Russian Federation in the conditions of the hybrid war being fought by it. ${ }^{6}$ The Doctrine as a strategic document is

${ }^{5}$ KONSTYTUTSIYA UKRAYINY (Vidomosti Verkhovnoyi Rady Ukrayiny (VVR), 1996, No. 30, st. 141) [Iz zminamy, vnesenymy zhidno iz Zakonamy No. 2222-IV vid 08.12.2004, VVR, 2005, No. 2, st. 44; No. 2952-VI vid 01.02.2011, VVR, 2011, No. 10 , st. 68 ; No. $586-$ VII vid 19.09.2013, VVR, 2014, No. 11 , st. 142; No. $742-$ VII vid 21.02.2014, VVR, 2014, No. 11, st. 143; No. 1401-VIII vid 02.06.2016, VVR, 2016, No. 28, st. 532], http://zakon1.rada.gov.ua/laws/show/254\%D0\%BA/96$\%$ D0\%B2\%D1\%80, Nov. 6, 2017.

${ }^{6}$ Cf.: Ukaz Prezydenta Ukrayiny vid 25 lyutoho 2017 roku No. 47/2017 Pro Doktrynu informatsiynoyi bezpeky U Ukrayiny, http://www.president.gov.ua/documents/472017-21374, Nov. 6, 2017. 
also concentrated on indicating the most important threats, in the form of information expansion or special information operations aimed at radicalization of moods, or opinions of an indicated enemy.

It should be emphasized that the solutions adopted in the strategic document quoted encompass both the issues concerning civil rights stemming from the democratic nature of the Ukrainian constitutional regime and proposals for practical solutions. However, these are not proposals on an operational level, which stems from the methodology and doctrinal nature of the document. It should rather be treated in terms of a strategy for the political and public communications of the Ukrainian authorities. The doctrine in question describes, among other things, the necessity of conducting cultural diplomacy in order to shape the international image of Ukraine, implementing e-administration solutions and popularizing access to public information, TV digitalization, development of local communication, and public debate. The fight against misinformation and destructive propaganda is to take the shape of strategic narration, understood as a specially prepared text for verbal dissemination in the process of strategic communication in order to influence the target group in terms of information. ${ }^{7}$

Thus, taking into account the content of the Information Security Doctrine of Ukraine, it can be stated that the document should be in fact treated as a concept for the strategic communication of the state. The solutions proposed in it are quite general, which is typical of such documents, setting out the directions of activities and the substantive scope of undertakings.

The document which sets out the ways of implementing the doctrine is the Concept for the promotion of Ukraine in the world and its interests in the global information space. The aim of the solutions proposed in this document is the protection of the political and economic interests of Ukraine and their popularization in the global information space. ${ }^{8}$ The main aspects that should be emphasized include, for example, increased presence of Ukraine in international events, engaging the diaspora, or calling on non-governmental institutions for the implementation of projects, e.g. concerning cultural diplomacy. The result of the implementation of the concept on the basis of annual action plans is to be the enhancement

7 Ibid.

8 Pozporyadzhennya Kabinet Ministriv Ukrayiny Pro skhvalennya Kontseptsiyi populyaryzatsiyi Ukrayiny u sviti ta prosuvannya interesiv Ukrayiny u svitovomu informatsiynomu prostori vid 11 zhovtnya 2016 r. No. 739-r. 
of the image of Ukraine as a reliable partner in the international arena and the increasing attractiveness of the country for tourism and investment.

\section{Institutional dimension}

Analyzing the institutional aspect, we should first of all mention the Committee of the Supreme Council on Freedom of Speech and Information Policy. ${ }^{9}$ As regards freedom of speech, we can point to the National Council of Television and Radio Broadcasting (Ukrainian: Національна рада Украӥни з питань телебачення і радіомовлення), which is a constitutional body. On the other hand, the State Committee for Television and Radio Broadcasting is a central body of executive power which is subordinate to the Cabinet of Ministers, being at the same time the founding and coordinating body for Ukrainian public media. ${ }^{10}$ However, due to the thematic scope of this article, attention will only be focused on the institutionalization of information policy in the strict sense.

However, Ukrainian information policy is implemented mainly by the Ministry of Information Policy which functions under the resolution of the Supreme Council of Ukraine and the regulation of the Cabinet of Ministers. ${ }^{11}$ Tasks allocated to the Ministry of Information Policy have been placed within the scope of information policy treated from the wider definitional perspective. This concerns, among other things, the organization of cultural events (which can be treated as a manifestation of public diplomacy), as well as the popularization of Ukrainian TV programs abroad, or disseminating information about Ukraine in the world, and even the protection of state secrets and classified information. Other aspects of the activities of the Ministry of Information Policy are connected with the implementation of European standards concerning guarantees of freedom of speech and freedom of the press, understood as the so-called fourth estate. The ministry also tackles public communication, development of access to public information and enhancing transparency in the function-

${ }^{9}$ http://komsvobslova.rada.gov.ua/, Nov. 16, 2017.

10 Polozhennya pro Derzhavnyy komitet telebachennya i radiomovlennya Ukrayiny zatverdzhene postanovoyu KMU vid 13.08.2014 No. 341.

11 Postanova Verkhovnoyi Rady Ukrayiny "Pro formuvannya skladu Kabinetu Ministriv Ukrayiny" (Vidomosti Verkhovnoyi Rady (VVR), 2014, No. 52, st. 2062); Polozhennya pro Ministerstvo informatsiynoyi polityky Ukrayiny, zatverdzheno postanovoyu Kabinetu Ministriv Ukrayiny vid 14 sichnya 2015 p. No. 2. 
ing of the administration. However, this mostly concerns the effective information war connected with the armed conflict in some areas of the eastern Ukrainian oblasts. ${ }^{12}$ This conflict is described by the Ukrainian state authorities as a counter-terrorism operation, and it is accordingly described in legal regulations, which in the axiological aspect unambiguously defines this issue from the communicational perspective.

The aims of the Ministry can be dychotomically divided into strategic and tactical priorities. They are both coherent with each other. An example of this is the strategic priority of the transparency of administrative activities, which significantly limits corruption. The objective of the assumed counter-propaganda, on the other hand, is to gain an information advantage, and as a consequence to succeed in the information war being fought in the occupied and liberated territories (i.e. Crimea and parts of the Luhansk and Donetsk oblasts).

However, it should be emphasized that the Ministry of Information Policy does not position itself as a propagandist or controlling institution, or as a body responsible for the political communication of the image of major state bodies. The Ministry declares that it is not responsible for information and psychological operations. ${ }^{13}$

From the point of view of the issues tackled in this article, the Ukrainian Information Agency UkrInform and UATV (Ukraine Tomorrow) are other key institutions for effective information policy. The activity of both is legitimated under the special act on the international broadcasting system. ${ }^{14}$ This act constitutes the functioning of the state broadcasting system of Ukraine, comprising the state-owned enterprise Multimedia Broadcasting Platform of Ukraine and the information agency UkrInform.

The publicly accessible agency website offers content in a few language versions. They ensure social reach for the strategic narration. Thus UATV, which has been broadcasting since October 2015, broadcasts in five language versions, including the language of the Crimean Tatars. Coverage in languages other than English cannot exceed half of the transmission time. This is connected with the international nature of the strategic narration broadcast on UATV. Besides being accessible on cable networks worldwide, UATV provides Internet streaming and the programs are also available on social and content media. However, the

12 http://mip.gov.ua/files/Presentation/en_pres.pdf, Nov. 19, 2017.

13 http://mip.gov.ua/files/documents/MIP_activity_2016_eng.pdf, Nov. 19, 2017.

14 Zakon Ukrayiny Pro systemu inomovlennya Ukrayiny (Vidomosti Verkhovnoyi Rady (VVR), 2016, No. 4, st. 37). 
program content of UATV does not contain a current news service. It is a TV channel whose target group is the audience abroad, informing about events in Ukraine and the activities of state bodies. The mission of UATV is creating a positive image of Ukraine in the international community, as well as promoting intercultural and international communication and creating a public discourse about the official stance of state and local authorities on important issues of politics, culture, sport and education, as well as science. The task of the TV channel is also information support for the process of the integration of Ukraine into the European Union and Euro-Atlantic structures, popularizing Ukrainian culture in the world and the promotion of Ukraine's investment attractiveness. ${ }^{15}$

Thus, considering the mission and tasks of Ukraine Tomorrow, it should be indicated that it is first and foremost a narrative propagandist medium aimed at the aggressive distribution of Ukrainian strategic narration.

However, it should be emphasized that the concept of synergy in the information policy implemented through the state-owned enterprise, the Multimedia Broadcasting Platform of Ukraine, and the state information agency UkrInform is still at an initial stage of implementation and the assessment of its effectiveness requires deeper research into the perception of news content.

Table 1

Popularity of the Ministry of Information Policy of Ukraine's profiles on social and content websites

\begin{tabular}{||l|c|c|c|c||}
\hline & Likes & Followers & Subscriptions & Views \\
\hline Facebook & 4,273 & 4,424 & & \\
\hline Twitter & & 5,339 & & \\
\hline Youtube & & & 1,116 & 570,576 \\
\hline Google + & & 32 & & \\
\hline
\end{tabular}

Source: Own elaboration, as of Nov 23, 2017.

Analyzing the popularity of the UATV and UkrInform profiles on social and content websites, a few conclusions can be drawn. First, video content is the most popular element in both institutions, considering the number of views. However, a more meaningful indicator is the number of subscriptions, which reflects the number of people following a given profile. Subscribing and following may be treated as a manifestation

${ }^{15}$ Zakon Ukrayiny Pro systemu inomovlennya Ukrayiny (Vidomosti Verkhovnoyi Rady (VVR), 2016, No. 4, st. 37), ctattya 6. 
of preferences, while views or likes may be incidental and reflect only the temporary interest of users. However, in the case of video content from UATV and UkrInform, the popularity of subscriptions mainly in the Ukrainian language version can be noticed, followed by the Russian and Arabic versions. The last two indications may be explained by the natural interest of Russian speaking people, both ethnic Russians and Ukrainians using Russian on an everyday basis. The interest in Arabic versions stems from the nature of the bonds between Muslims. The territory of Crimea annexed by the Russian Federation is inhabited by a considerable group of Tatars, who share religion with the Arab community ${ }^{16}$ The popularity of the Ukrainian language version as regards profiles on Facebook and Twitter may demonstrate the tendency to awaken Ukrainians' national consciousness. The informational and political conflict with Russia has become a catalyst for the consolidation of Ukrainian national consciousness which, in combination with the propagandist narrative of the UATV television channel, influences the rising sense of belonging and national pride. The analysis of UATV information content may indicate that this channel practices white propaganda - which is external and in this case serves the information and interpretative function used to build a persuasive message (Piechota, Rajczyk, 2016, pp. 234-235).

To sum up the institutional aspect of information policy of Ukraine, it should first of all be emphasized that the content on new media is not very popular. This may be explained by the brief period of the UATV channel's functioning, the lack of its own website and poor positioning of the domain address on the Internet. Moreover, the language versions of profiles on social and content media are not the same. In the case of Instagram and Youtube, the Ukrainian language version prevails. The domination of the Ukrainian language version is incompatible with the simultaneously addressing the message to the foreign audience as regards the objectives. Adding other language versions on profiles offered on social and content media will thus be necessary. An important communication synergy effect must also be noted. UATV does not broadcast the latest news bulletins, but instead concentrates on the informative-interpretative function, nevertheless retaining elements of news broadcast live in the form of news bars in Ukrainian and English. However, the informative function dominates in the activities of UkrInform.

${ }^{16}$ According to data from the Ministry of Information Policy of Ukraine, the Tatar community in Ukraine including Crimea, is estimated at about 350,000 people. 


\section{Operational dimension}

The campaigns carried out by the Ministry of Information Policy can be divided into categories determined by their type: social, informational and persuasive. The category of social campaigns concerns the activities that are aimed at explaining social policy initiatives to the citizens of Ukraine (aid for internal resettlers, access to social aid) and the necessity of changes in the fees for municipal services. Although the decision about increased fees caused social protests, from the narrative side it has been presented as a fight for Ukraine's energy independence. ${ }^{17}$ Information campaigns, on the other hand, are concentrated on implementing the integrative function, and they concern, among other things, the promotion of the Ukrainian Armed Forces, state holiday celebrations, interethnic integration, ${ }^{18}$ as well as popularizing learning foreign languages or promoting structural reforms, such as the decentralization of the state. ${ }^{19}$

Finally, the persuasive campaigns mainly encompass issues connected with the counter-terrorism operations carried out in the eastern regions of Ukraine and in Crimea annexed by the Russian Federation. An example of this is the project Ukraine's information army (http://i-army. org) aimed at fighting anti-Ukrainian propaganda by creating a community using so-called swarm technology. ${ }^{20}$ However, with regard to Crimea, the persuasive campaigns conducted are aimed at the integration of the Tatar community or support for the reintegration of Crimea with Ukraine..$^{21}$

The operational aspect of Ukrainian information policy is thus characterized by a diversity of forms and content and the use of modern communication techniques also based on new media, but social campaigns are first of all highly utilitarian. ${ }^{22}$ Both social campaigns, and information or persuasive campaigns are a response to the real needs of citizens and the

17 http://mip.gov.ua/content/energetichna-efektivnist.html, Nov. 26, 2017.

18 This concerns the campaign: Three nations, one root presenting Ukraine's ethnic diversity - see https:/www.youtube.com/watch? $\mathrm{v}=\mathrm{sSxfoW}$ f-A\&feature=youtu. be, Nov. 26, 2017.

19 http://mip.gov.ua/en/news/1975.html, Nov. 26, 2017.

20 The project's Youtube profile has over 1.5 million views and over 6,500 subscriptions, 29,900 followers on Twitter, 43,705 followers and 43,740 likes on Facebook, 1,308 on Google+ and 7,826 followers on VKontakte.

${ }^{21}$ http://mip.gov.ua/en/news/285.html, Nov. 26, 2017.

22 http://mip.gov.ua/en/content/uryadovi-proekti.html, Nov. 26, 2017. 
problems that Ukraine is encountering while introducing systemic and structural reforms.

On the other hand, analyzing the popularity of the profiles of the Ministry of Information Policy on social and content networks, it should be indicated that the Ministry itself, with its corporate message, is less popular than its projects intensively communicated and promoted on social media. This is evidence of a high degree of communication effectiveness of the projects, which is the result of the professionalization of the Ministry's staff.

\section{Conclusion}

The above analysis of Ukrainian information policy confirmed the main research hypothesis of this article, and also its secondary nature to strategic communication, mainly due to the fact that information policy does not encompass the current information activities of the Ukrainian government. The factors determining Ukrainian information policy can be divided into economic, social or political. In the first group, the need to increase the attractiveness of the state for investment and tourism should be taken into consideration. In the second group, national and social integration and, as regards political factors, information policy is mainly shaped by the geopolitical situation of Ukraine. This undoubtedly means the correlation between information policy and strategic communication of the country. Information policy is thus, in fact, one of the tools used in Ukrainian strategic communication. An important novelty is including information policy as part of the information security of a country, which is understood as the protection of information space from foreign propaganda influence. Educational campaigns fight with misinformation and enemy propaganda, which take place in the process of fake news transmission. The methodological approach to the issue of information policy on the part of its managers is also worth emphasizing. The constitutional approach to this issue in connection with the strategic aspect - the Information Security Doctrine - and the operational aspect - the Concept of promotion of Ukraine in the world and its interests in the global information space - makes it possible to conclude that Ukrainian information policy is entering an institutionalization and professionalization phase, which will undoubtedly influence the level of its effectiveness. 


\section{Bibliography}

Buhmann A., Ingenhoff D. (2015), The 4D Model of the country image: An integrative approach from the perspective of communication management, "The International Communication Gazette," vol. 1, no. 77.

Castells M. (2006), Mobile Communications and Society; A Global Perspective, MIT Press, Cambridge.

Castells M. (2013), Sieci oburzenia i nadziei. Ruchy spoteczne w erze internetu, Wydawnictwo Naukowe PWN, Warszawa.

de Zuniga G. H., Puig-i-Abril E., Rojas H. (2009), Weblogs, traditional sources and political participation: An assessment of how the internet is changing the political environment, "New Media and Society," no. 11.

Dobek-Ostrowska B. (2006), Komunikowanie polityczne i publiczne, PWN, Warszawa.

Edwards G. (2014), Social Movements and Protest, Cambridge University Press, Cambridge.

Eisenstadt S. N., Giesen B. (1995), The Construction of Collective Identity, "European Journal of Sociology," vol. 36, no. 1.

Hubenko D., Wall M. (2018), The networked public sphere and Ukrainian journalists, in: Social Media and Politics in Central and Eastern Europe, eds. P. Surowiec, V. Štětka, Routledge New York.

Juris J. S. (2005), The New Digital Media and Activist Networking within Anti-Corporate Globalization Movements, "Annals. American Academy of Political and Social Science," no. 597.

Kacała T., Lipińska J. (2017), Komunikacja strategiczna i Public Affairs [Strategic Communication and Public Affairs], Wojskowe Centrum Edukacji Obywatelskiej, Warszawa.

Krzyżanowski M. (2008), Konstrukcja tożsamości narodowych i europejskich w polskim dyskursie politycznym po roku 1989: analiza dyskursywno-historyczna [Construction of national and European identities in Polish political discourse after 1989: a discourse-historical analysis], in: Krytyczna analiza dyskursu. Interdyscyplinarne podejście do komunikacji społecznej, eds. N. Fairclough, A. Dusza, Wydawnictwo Universitas, Kraków.

Maćkowska R. (2010), Zaspokajanie potrzeb informacyjnych a aktywizacja spoleczności lokalnej [Satisfying information needs and activation of local community], in: Rola samorzqdu terytorialnego $w$ modernizacji Polski [The role of local authorities in Poland's modernization], eds. M. Barański, A. Czyż, S. Kubas, Wydawnictwo Uniwersytetu Śląskiego, Katowice.

Mutz D. C., Young L. (2011), Communication and Public Opinion, "Public Opinion Quarterly," no. 75.

Nye J. S. (2007), Jak osiagnać sukces w polityce światowej [Soft power. The Means to Success in World Politics], Wydawnictwo Akademickie i Profesjonalne, Warszawa. 
Ociepka B. (2008), Dyplomacja publiczna jako forma komunikowania [Public diplomacy as a form of communication], in: Dyplomacja publiczna [Public Diplomacy], ed. B. Ociepka, Wydawnictwo Uniwersytetu Wrocławskiego, Wrocław.

Ociepka B. (2013), Miękka siła i dyplomacja publiczna Polski [Soft Power and Poland's Public Diplomacy], Wydawnictwo Scholar, Warszawa.

Piechota G., Rajczyk R. (2015), The role of social media during protests on Maidan, "Communication Today," vol. 6, no. 2.

Piechota G., Rajczyk R. (2016), Przejawy rosyjskiej propagandy w Polsce w przestrzeni nowych mediów [Manifestations of Russian propaganda in Poland in the space of new media], in: Obrazy Rosji i Rosjan w mediach [Images of Russia and Russians in the Media], eds. I. Hofman, J. Maguś, Wydawnictwo UMCS, Lublin.

Rajczyk R. (2016), Nowoczesne wojny informacyjne [Modern Information Wars], Wydawnictwo Difin, Warszawa.

Reznik O. (2016), From the Orange Revolution to the Revolution of Dignity: Dynamics of the Protest Actions in Ukraine, "East European Politics and Societies and Culture," vol. 30, no. 4.

Turcotte J., York C., Irving J., Scholl R. M., Pingree R. J. (2015), News recommendations from social media opinion leaders: Effects on media trust and information seeking, "Journal of Computer-Mediated Communication," no. 20.

Seib P. (2012), Real-Time Democracy; Politics and Power in the Social Media Era, Palgrave MacMillan, New York.

Weeks B. E., Holbert R. L. (2013), Predicting dissemination of news content in social media: A focus on reception, fending and partisanship, "Journalism and Mass Communication Quarterly," no. 90.

\section{Instytucjonalizacja ukraińskiej polityki informacyjnej, jako funkcja komunikacji strategicznej}

\section{Streszczenie}

Celem artykułu jest analiza ukraińskiej polityki informacyjnej. W badaniu uwagę skoncentrowano na władzy wykonawczej ze względu na fakt, że to egzekutywa w znaczący sposób wpływa na wizerunek wewnętrzny i zewnętrzny państwa ukraińskiego. Analizę przeprowadzono w ujęciu ilościowym, podczas którego namysłowi naukowemu poddano nadawane treści. Ocenie naukowej poddano także efektywność strukturalną realizowanej polityki informacyjnej oraz jej aspekt utylitarny.

Słowa kluczowe: polityka informacyjna, UATV, Rewolucja Godności, Ministerstwo Polityki Informacyjnej, Ukraina 